\title{
Restoration of Heart Function Using Transplantation of Human Umbilical Cord Matrix-Derived Cardiomyocytes and Vascular Endothelial Growth Factor
}

\author{
Moradi Kaveh $^{1}$, Abbasi Mehdi ${ }^{1 *}$, Aboulhasani Farid ${ }^{1}$, Rastegar Tayebeh ${ }^{1}$, Asgari Hamidreza ${ }^{1}$, \\ Abbasi Majid ${ }^{1}$, Latifpour Mostafa ${ }^{1}$, Koruji Morteza ${ }^{2}$, Sargolzaei Aval Fereidon ${ }^{3}$, Salehi Majid ${ }^{4}$ \\ and Mohammadi Rad Mosleh ${ }^{5}$ \\ ${ }^{I}$ Department of Anatomical Science, School of Medicine, Tehran University of Medical Sciences, Tehran, Iran \\ ${ }^{2}$ Cellular and Molecular Research Center \& Department of Anatomical Science, School of Medicine, Iran University of \\ Medical Sciences, Tehran, Iran \\ ${ }^{3}$ Department of Anatomical Science, School of Medicine, Zahedan University of Medical Sciences, Zahedan, Iran \\ ${ }^{4}$ Medical Nanotechnology Department, Tehran University of Medical Sciences, Tehran, Iran \\ ${ }^{5}$ Institute of Biochemistry and Biophysics, University of Tehran, Tehran, Iran
}

\begin{abstract}
Objectives: In the previous study, although it has been shown that intramyocardial injection of human umbilical cord matrix stem cell (hUCM) improved cardiac function 4 weeks post MI, but angiogenesis has not been observed. Angiogenesis and replacing lost cardiomyocytes with new, live cardiomyocytes are considered as two key agents in cardiac repair. To achieve the above two factors we examined the effects of combination of stem cell and angiogenic therapy approaches by simultaneously injection of hUCM-derived cardiomyocytes with vascular endothelial growth factor (VEGF) in cardiac repair.

Methods: MI-induced animals(by ligation of LAD) received $50 \mu 1 \mathrm{PBS}, 5 \times 10^{6}$ differentiated hUCM cells (dhUCM), $5 \mu \mathrm{g}$ VEGF in normal saline and $5 \times 10^{6} \mathrm{dhUCM}$ cells combined with $5 \mu \mathrm{g}$ VEGF in normal saline, intramyocardialy. MI group, with no other intervention, served as a control group. We were assessed survival, migration and integration of dhUCM cells, as well as angiogenesis eight weeks post MI induction.

Results: Eight weeks post MI, although dhUCM and VEGF groups have shown that LVEF and LVFS improved significantly, but animals in dhUCM+VEGF group have the highest rise in LVEF and LVFS in comparison to the other MI-induced groups $(\mathrm{p}<0.05)$. Histological and morphological analysis have revealed that myocardium of animals in dhUCM+VEGF group have the highest vascular density and the lowest fibrosis tissue in comparison to the other MIinduced groups $(\mathrm{p}<0.05)$. Immunohistological assessments revealed that transplanted dhUCM cells have survived, migrated to infarcted area and integrated with recipient cardiac tissue.

Conclusion: we have found that intramyocardial administration of dhUCM cells combined with VEGF improved cardiac function, enhanced angiogenesis and reduced fibrosis tissue formation after MI, eight weeks post MI.
\end{abstract}

Keywords: Human Umbilical Cord Matrix-derivedcardiomyocytes, Myocardial infarction, Angiogenesis, Vascular endothelial growth factor, Cell therapy, Cardiac repair, Rabbit.

\section{INTRODUCTION}

Myocardial infarction and the subsequent heart failure are the main causes of morbidity and mortality in western societies [1]. Myocardial infarction is defined as the loss of cardiomyocytes, mostly due to reduced or obstructed blood flow which leads to impaired cardiac function [1,2]. Despite many recent advances in surgical and medical therapy, infarcted heart therapies need to take more effort and time to

*Address correspondence to this author at the Department of Anatomical Science, School of Medicine, Tehran University of Medical Sciences, Tehran, Iran; Tel: 9821 64432348; Fax: 9821 66419072;

E-mail: abbasima@sina.tums.ac.ir replace lost cardio myocytes and cardiac regeneration. Limited regenerative capacity of the heart has forced scientists to focus on novel therapeutic approaches, such as stem cell and angiogenic therapy, for the treatment of the heart [3-7]. Angiogenesis, defined as the formation of new vessels from existing ones, is a key factor in cardiac repair following myocardial infarction, without which cardiac rupture and fibrosis tissue formation would occur [8]. Nevertheless, angiogenic therapy using VEGF has indicated that the administration of VEGF in infarcted myocardium induces angiogenesis, decreases apoptosis and improves cardiac function. However, cardiac repair requires the replacement of lost cardio myocytes with new, alive cardio myocytes [9-11]. Numerous studies have shown the potential 
of stem cell therapy in replacing lost cardiomyocytes, reducing infarcted size, making less ventricular remodeling and the improvement of cardiac function [12-15]. Each source of stem cells has advantages and disadvantages; currently, hUCM cells are considered for use mostly due to their great expansion capability, non-invasive, comfortable isolation procedure and low risk of immune system reaction and teratoma formation in the recipient [16-20]. Therapeutic potentials of hUCM have been proved for the treatment of some diseases, but their use for myocardial infarction is not well understood yet and therefore its application requires more assessment [21-24]. Latifpour et al. have shown that transplantation of hUCM cells in to infarcted myocardium improved left ventricular function 30 days post MI, however, angiogenesis was never observed [25]. On the other hand, precise assessment of hUCM's effects in cardiac regeneration needs more time than 30 days. We assume that the combination of stem cell therapy and angiogenic therapy approaches in the treatment of infarcted heart will cover the limitations related to each one of them and optimize their positive effects.

Here we will describe the results of intramyocardial injection of hUCM- derived cardiomyocytes with and without VEGF into infarcted myocardium on heart function eight weeks post MI. In addition, we will assess survival, migration and integration of dhUCM cells, as well as angiogenesis by histopathological analyses eight weeks after the transplantation in to infarcted rabbit's heart.

\section{MATERIALS AND METHODS}

\section{Preparation of hUCM Cells}

Umbilical cords were collected after the birth with informed consent of the parents, and were transported to the laboratory in mediums containing Hank's balanced salt solution (HBSS)(Gibco, USA). Within two hours after the collection, under sterile condition, umbilical cord blood vessels were cleared off, and the remained matrices were minced into fragments; these fragments were rinsed with PBS, and then were cultured in culture plates containing a complete medium (DMEM-F12 supplemented with $15 \%$ FBS(Gibco, USA), $100 \mathrm{U} / \mathrm{ml}$ penicillin, $60 \mu \mathrm{g} / \mathrm{ml}$ streptomycin). The culture plates were incubated under humidified condition in $5 \% \mathrm{CO}_{2}$ in a $37^{\circ} \mathrm{C}$ incubator. The medium was changed until fibroblast shaped cells that adhered to the floor of the plates were seen. The fragments were discarded, the cells were trypsinized and suspended in DMEM, and then were cultured in a new complete medium. The mediums were changed every three days.

\section{Flow Cytometric Analysis of hUCM Cells}

HUMC cells were lifted by trypsin and were suspended in DMEM, $1 \times 10^{6}$ cells $/ \mathrm{ml}$ hUCM cells were fixed with $4 \%$ paraformaldehyde and were incubated in PBS with $2 \%$ normal serum. HUCM cells were incubated with primary antibodies (antibodies against CD73, CD29, CD34, CD44, CD45, CD90, CD105, HLA-ABC (HLA-1) and HLA-DR (all ebiosciences, USA) as described in previous studies [16, 21]) at room temperature followed by fluorescent secondary antibodies. Control hUCM cells were stained with a secondary antibody alone. AFACS can machine (Becton, Dickinson) was used for the flow cytometric analysis.
The Induction of Adipogenic, Chondrogenic, or Osteogenic Differentiation

HUCM cells were induced to differentiate them into adipogenic linage cells by incubation with serum-free DMEM containing $10 \%$ FBS, $50 \mu \mathrm{g} / \mathrm{ml}$ of ascorbate- 1 phosphate, $100 \mathrm{nMdexamethasone}$ and $50 \mu \mathrm{g} / \mathrm{ml}$ indomethacin [Sigma, St. Louis]), into chodrogenic linage by incubating them with serum-free DMEM containing insulintransferr in-selenium (ITS) + premix [GIBCO, Carlsbad, $\mathrm{CA}$ ] and $10 \mathrm{ng} / \mathrm{ml}$ transforming growth factor [TGF]- $\beta 1$ [PeproTech, Rocky Hill, NJ]) and into osteogenic linage by incubating them with (DMEM-LG containing 10\% FBS, 50 $\mu \mathrm{g} / \mathrm{ml}$ ascorbate- 2 phosphate, $10 \mathrm{nM}$ dexamethasone, and 10 $\mathrm{mM} \beta$-glycero-phosphate. Three weeks later, after the fixation of hUCM cells by paraformaldehyde in PBS, these cells underwent Alcian blue, oil red and Alizarin red staining for the detection of chondrogenic, adipogenic and osteogenic differentiation, respectively.

\section{Cardiac Differentiation of hUCM cells}

In vitro, the differentiation of hUCM cells into cardiomyocytes was induced by incubating hUCM cells with cardiogenic differentiation medium containing complete medium and 10nM Oxytocin (Wako chemical, Germany) for $72 \mathrm{~h}$ [26]. Then the differentiation medium was replaced with complete medium, and was regularly refreshed every three days, for three weeks.

\section{Immnuocy to Chemical Analysis}

Oxytocin- treated cells (dhUCM) were washed with PBS and fixed with $4 \%$ formaldehyde (Sigma, USA) for 10 minutes at room temperature. These cells permeabilized with $0.1 \%$ triton X-100 (Sigma, USA) in PBS for 15 minutes, and then were incubated with primary antibodies against cardiac troponin T (cTnT, abcam, UK), sarcomeric actin (sA, abcam, UK), cardiac actin (cA, sigma, USA) and connexin 43 (Cx43, millopore, Germany) followed by fluorescent secondary antibodies(FITC and Alexa Fluor). HUCM cells served as a control. Controls for nonspecific binding of secondary antibodies were performed by excluding primary antibodies.

\section{Labeling of the dhUCM Cells with DiI}

Cell tracker CM-DiI (Invitrogen, USA) was prepared in dimethylsulfoxide at $2 \mathrm{mg} / \mathrm{ml}$ and diluted into HBSS (5 $\mu \mathrm{l} / \mathrm{ml})$. HUCM and dhUCM cells were labeled by these labeling -solution ( $2 \mathrm{ml}$ added into every tissue culture flask) and incubated in $37^{\circ} \mathrm{C}$ incubator for ten minutes. The cells were prepared for transplantation in this way.

\section{Induction of Myocardial Infarction (MI) Model and Cell Transplantation}

This investigation was performed in accordance with the principles of the ethical committee at Tehran University of Medical Science, Iran. 60 male New Zealand white rabbits (weight range $2.5-3 \mathrm{~kg}$ ) were randomly divided into six groups: (a) intact group (non-MI, $\mathrm{n}=10$ ); (b) MI group $(n=10)$ consisting of MI model; (c) PBS group $(n=10) ;(d)$ dhUCM group $(n=10)$; (e) VEGF group $(n=10)$; (f) dhUCM + VEGF group $(n=10)$ consisting of MI model with PBS, dhUCM cells, VEGF and dhUCM cells combined with VEGF were injected into the margin of MI region in four 

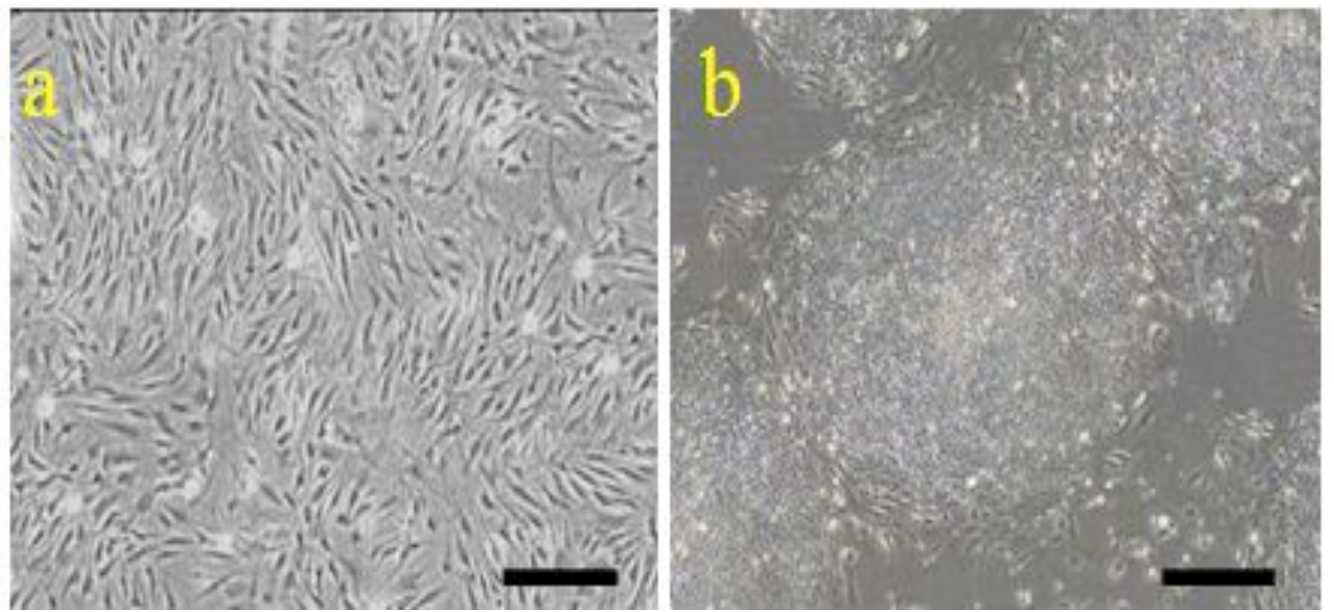

Fig. (1). The hUCM cells appeared in spindle shape cells possess cytoplasmic extensions (a) and high potential of colony formation (b). Scale bar: $100 \mu$

sites, respectively. Rabbits were anesthetized, in tubated and ventilated using a ventilator. After the left thoracotomy, a 0.6 silk ligature was placed and tied closely around the proximal end of the left anterior descending artery (LAD). One hour later, the induction of MI-model was confirmed by a cyanotic appearance of the infarcted area, then $50 \mu 1$ PBS, $5 \times 10^{6}$ dhUCM cells, $5 \mu \mathrm{g}$ VEGF in normal saline and $5 \times 10^{6}$ dhUCM cells combined with $5 \mu \mathrm{g}$ VEGF in normal saline injection was performed in (c, d, e, f) groups, respectively. The injections were applied using an insulin syringe with cooperated 28 gauge needle into the border zone of the infarcted area to maximize graft viability. Animals in group (a) underwent the same procedure without the ligation of the LAD. Cyclosporine A $(10 \mathrm{mg} / \mathrm{kg}$, subcutaneously) was given $24 \mathrm{~h}$ before the cell therapy and once daily, thereafter.

\section{Functional Assessment by Echocardiography}

Echocardiography was performed using a transthorasic echocardiographic device (Vivid3; General Electric) equipped with a 5-MHz linear transducer, five days, four and eight weeks after MI in all of the groups. The echocardiogram provided the following measurements including: ejection fraction (EF) and fractional shortening (FS). The Cardiologist that performed echocardiographic evaluation was not aware of the treatment groups.

\section{Morphometric and Histological Analysis}

Eight weeks after the injection, animals from each group was sacrificed, their hearts were excised and sliced into four segments from apex to the site of ligation. Then these segments were fixed in $10 \%$ formaldehyde, were prepared as embedded in paraffin and $5 \mu \mathrm{m}$ thick sections and stained with hematoxylin and eosin (H\&E). Some selected sections were incubated with primary antibody against CD31 (Bioscience, USA), followed by peroxidase conjugated secondary antibody, each one for one hour at room temperature. CD31-positive cells with a vascular structure were counted as a vessel (capillary or artery). The sections underwent trichromemasson staining for the evaluation of the amount of fibrosis tissue using MATLAB software (Mathworks Inc., Natick, MA, USA). Vascular density and fibrosis tissue of myocardium have been quantified as previously described in previous studies [27, 28].

\section{Immuno Histochemical Analysis}

Survival, migration and integration with recipient cardiac tissue of transplanted dhUCM cells were assessed by tracking DiI-labeled cells using fluorescence microscope as well as by immunohistological evaluation as the following: The sections were incubated in $3 \% \mathrm{H}_{2} \mathrm{O}_{2}$, blocked in $5 \%$ normal goat serum, then incubated with primary antibody, overnight at $4{ }^{\circ} \mathrm{C}$ with primary antibodies against cardiac $\alpha$ actinin (cAn, Sigma, USA), cardiac troponin $\mathrm{T}$ (cTnT, Sigma, USA) and connexin 43 (Cx43, Millopre, Germany) followed by FITC and Alexa Fluor for one hour.

\section{Statistical Analysis}

Statistical analysis was conducted with ANOVA using SPSS 19.0 software. A P value of $<0.05$ was considered significant. Data is expressed as means $\pm \mathrm{SD}$.

\section{RESULTS}

\section{Morphology and Flowcytometry Analysis of hUCM Cells}

10-15 days after the initiation of hUCM segment cultures, hUCM cells were expanded from matrix segments, then separated from segments and cultured in new mediums. These cells demonstrated short doubling time(16-24h), strong proliferative ability, and high potential of colony formation(colonies formed within 3-4 days); they adhered to the floor of tissue culture flask, and appeared in spindle/fibroblast shape cells with different size cytoplasmic processes which remained in similar morphology after several passages (Fig. 1a,b). The isolated hUCM cells from four different umbilical cords at passage fourwere selected for flow cytometry. The results of the flowcytometric analysis suggested that hUCM cells were positive for mesenchymal specific markers(CD73(98\%), CD29(94\%), CD44(89\%), CD90(91\%)) and were negative for CD34 and CD45, which indicated that hUCM cells did not belong to endothelial or hematopoietic linages. Moreover, hUCM cells showed HLA-ABC(95\%)but didn't show HLA-DR; this fact proves that these cells have a low risk of recipient inflammatory reaction (Fig. 2). The mesenchymal entity of hUCM cells was approved following their differentiation into chondrogenic, osteogenic and adipogenic linages (Fig. 3a-c). 

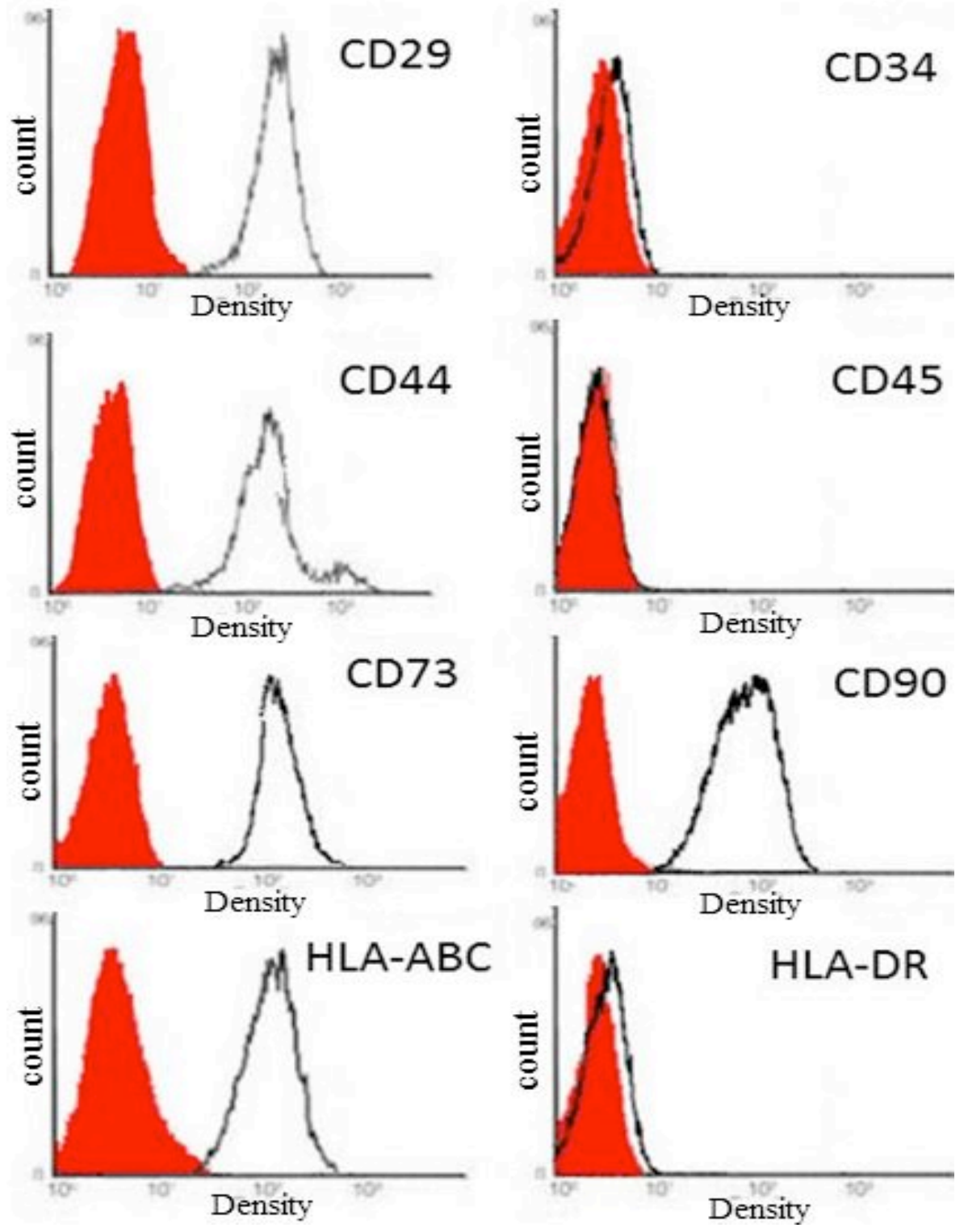

Fig. (2). Flow cytometric analysis of hUCM cells. Red histogram indicates background signal; open histogram represents positive reactivity with the indicated antibody. HUCM cells have expressed the mesenchymal specific markers (CD29, CD44, CD73 and CD90), but didn't express hematopoietic specific markers (CD34 and CD45). As you see, hUCM cells were positive for HLA-1 but negative for HLA-DR which indicated the low risk of recipient inflammatory reaction. The represented data obtained after 3 experiments.
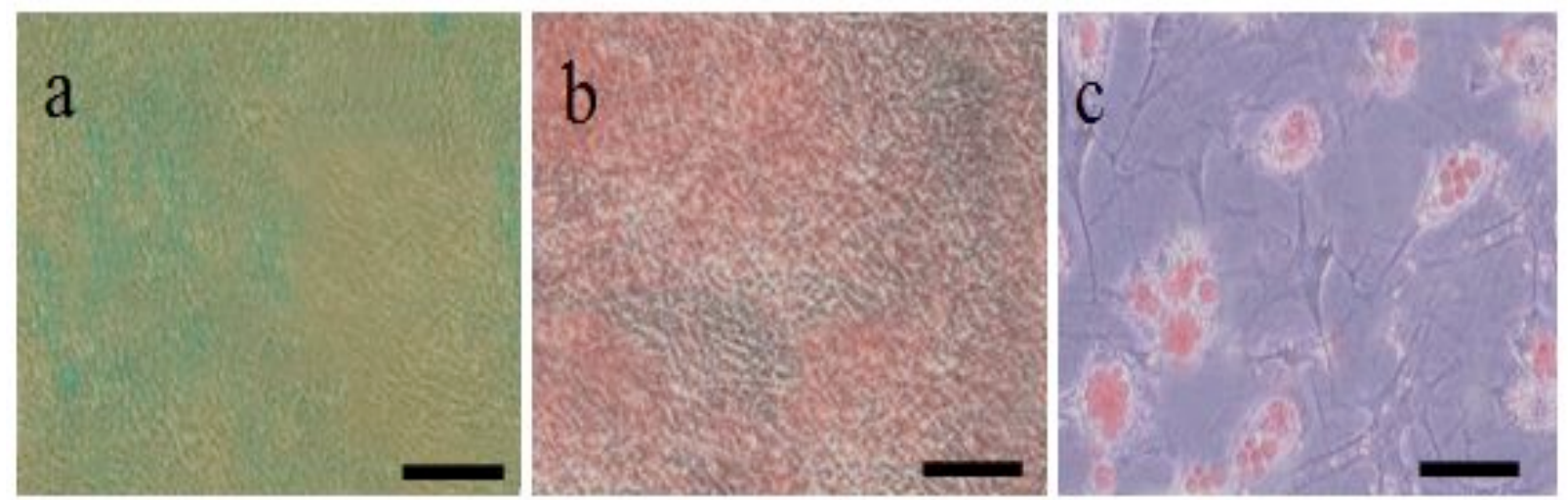

Fig. (3). Mesenchymal entity of hUCM stem cells. Chondrogenic differentiation verified by Alcian blue Staining (a) Scale bar: $100 \mu$. Osteogenic differentiation verified by Alizarin Red Staining (b). Scale bar: $100 \mu$. Adipogenic differentiation approved by Oil-Red Staining (c) Scale bar: $50 \mu$. 

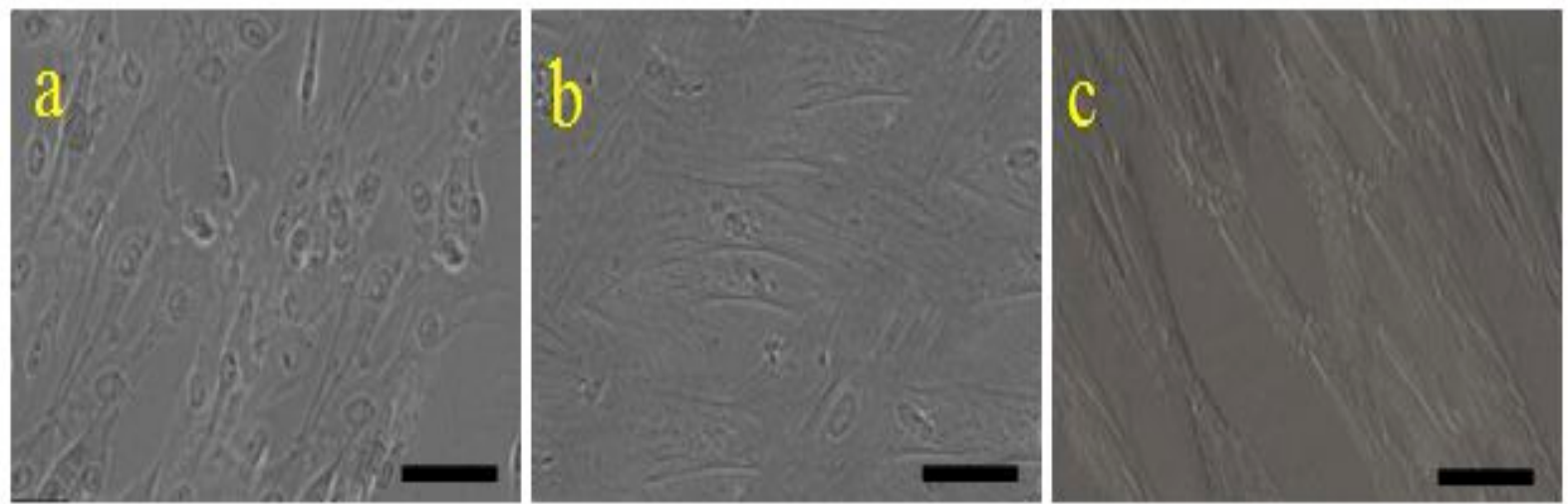

Fig. (4). Cardiac Differentiation of hUCM cells. Fibroblast shape hUCM cells (a) were turned into flat shape cells with short cytoplasmic extensions as cardiomyocytes. Fibrillar structure and spontaneous beating of dhUCM cells were seen under light (b) and phase contrast microscope (c). Scale bar: $50 \mu$
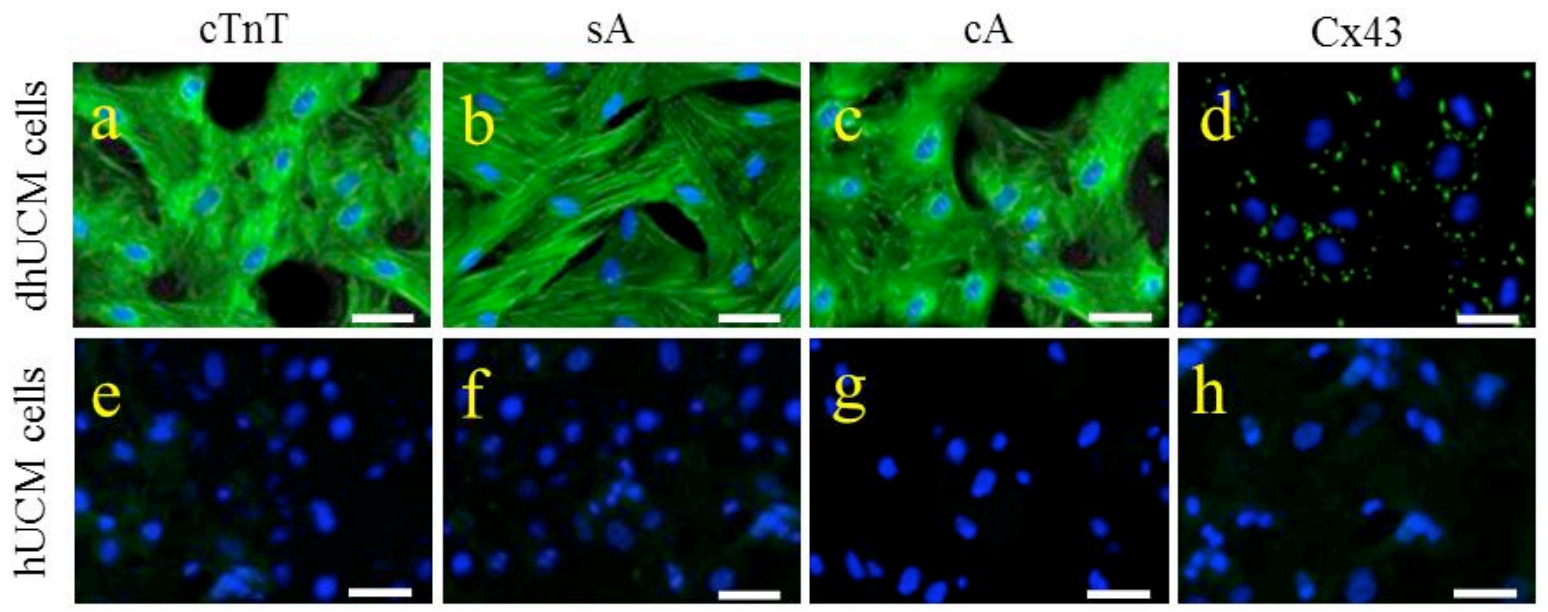

Fig. (5). Immunohistological analysis have shown that dUCM cells were positive for cardiac troponin $\mathrm{T}$ (cTnT), sarcomeric actin (sA), cardiac actin (cA) and connexin 43 (Cx43). The hUCM cells as a control group were negative for these cardiac specific proteins and didn't express any one of them. ). Cell's nuclei stained by DAPI. Scale bar $=50 \mu \mathrm{m}$.

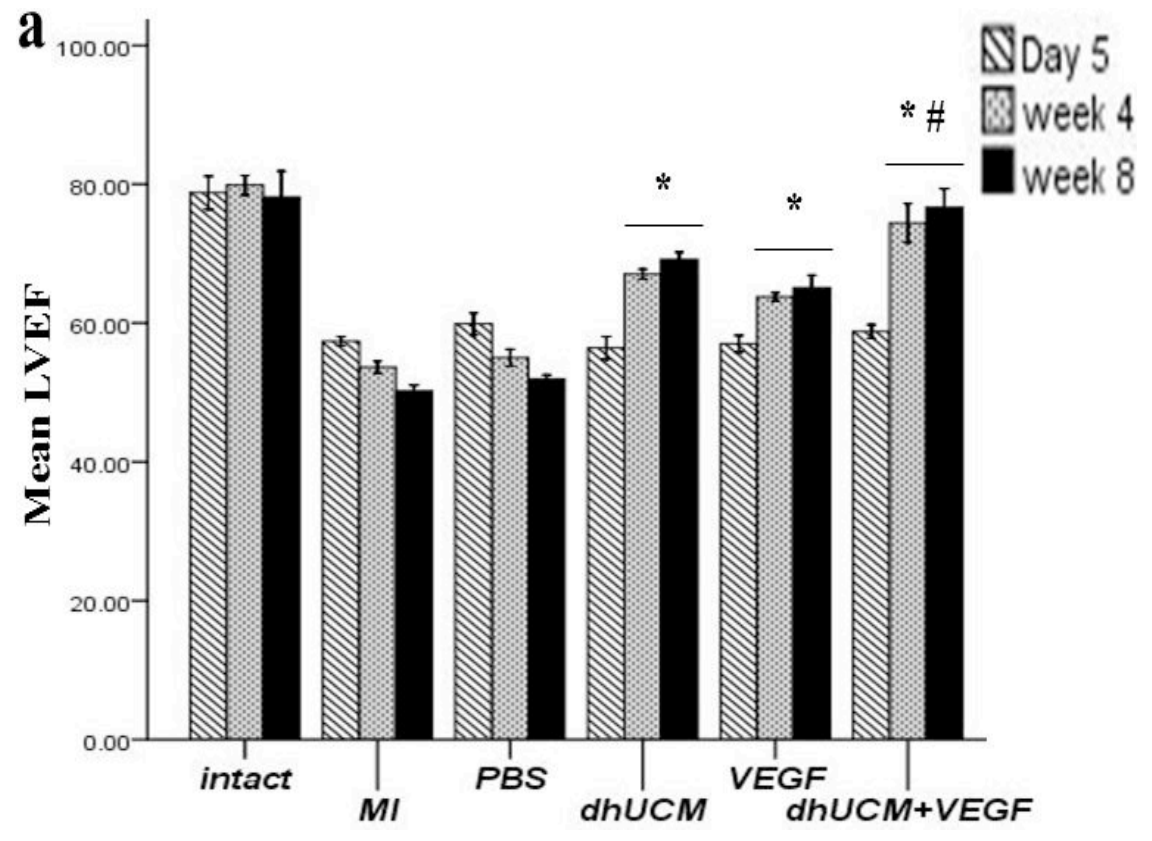




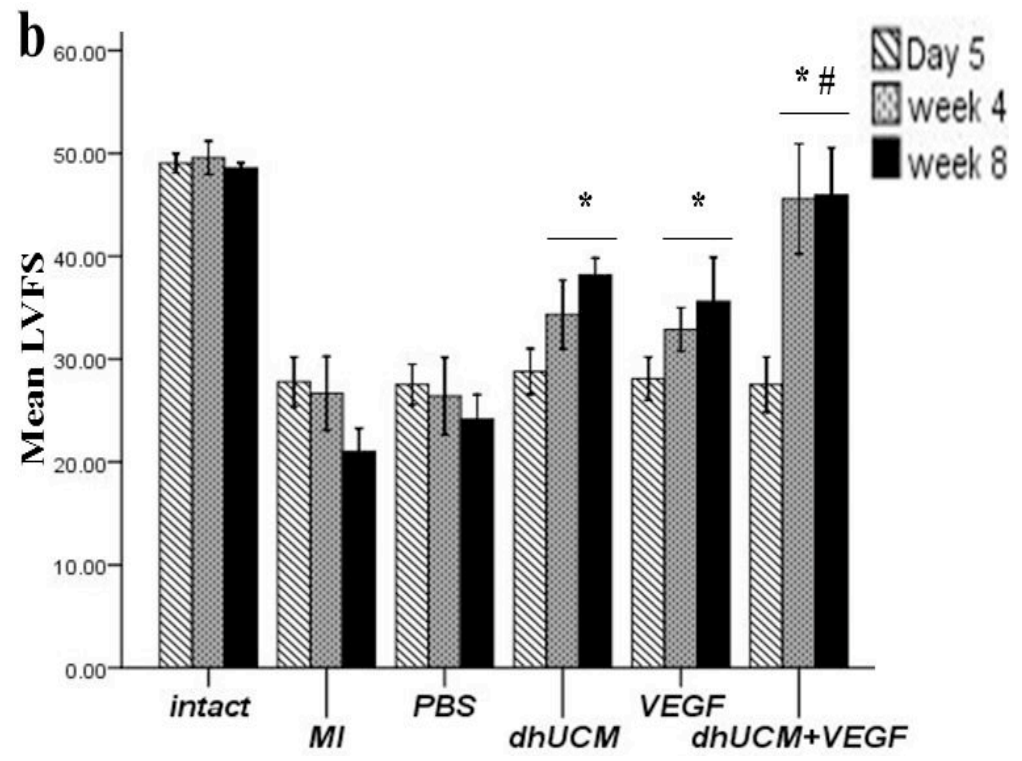

Fig. (6). Echocardiography assessments were applied in different time points. After 8 weeks, the treated animals by dhUCM cells combined with VEGF have shown the highest significant improvement in left ventricular function as well as animals in dhCUM and VEGF groups have demonstrated the increasing of EF (a) and FS (b) compare to MI and PBS groups with a significant difference.

$\mathbf{a}$
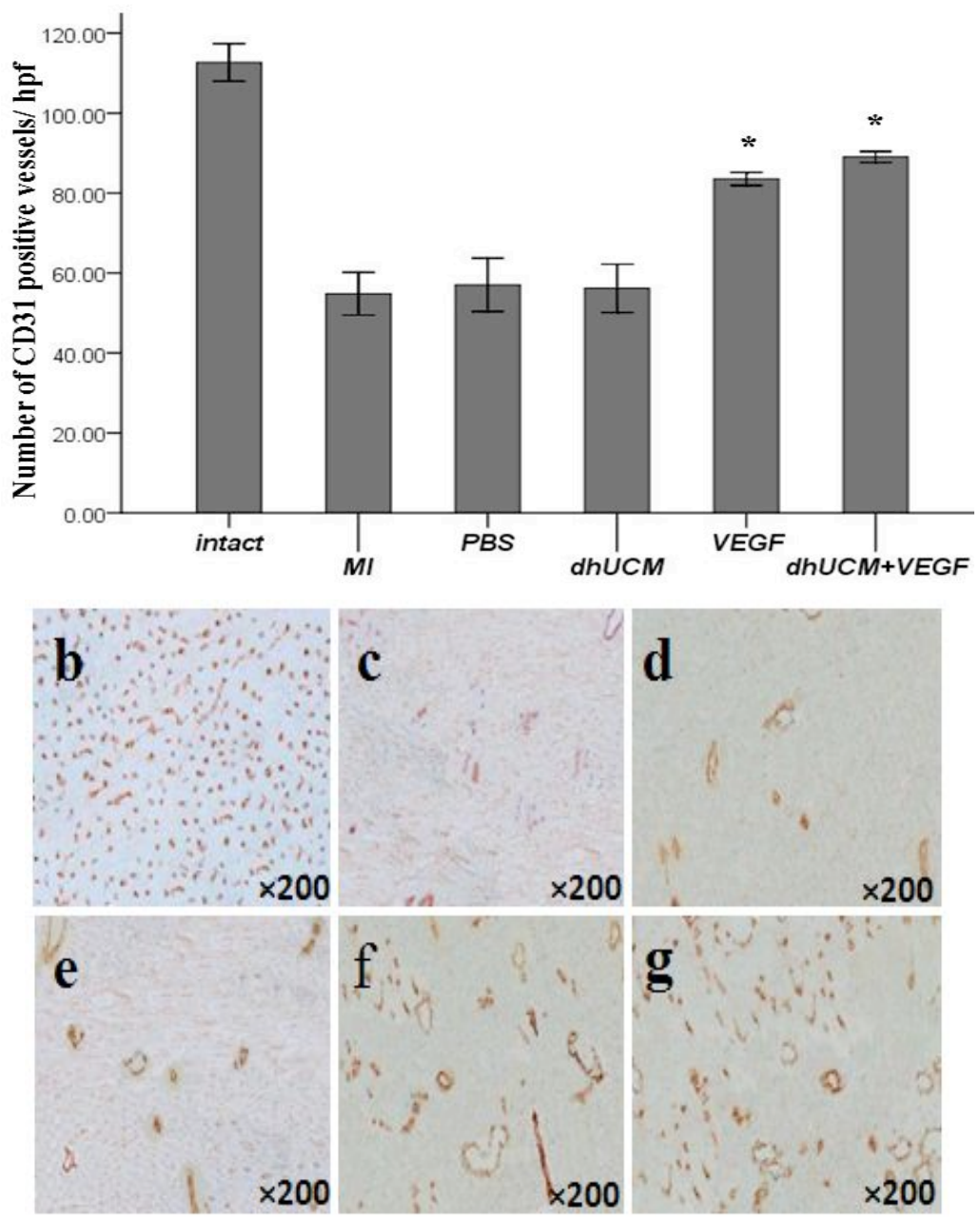

Fig. (7). Vascular density. bar graphs showing the quantification of CD31 positive vessels per high power field of microscope (a). Representative micrographs $(\times 200)$ have shown the blood vessels after CD31 staining 8 weeks post MI in intact (b), MI (c), PBS (d), dhUCM (e), VEGF (f) and dhUCM + VEGF (g) groups, respectively.* $\mathrm{p}<0.05$ vs. MI, PBS and dhUCM.

$* \mathrm{p}<0.05$ vs. MI and PBS.\# $\mathrm{p}<0.05$ vs. dhUCM and VEGF. 


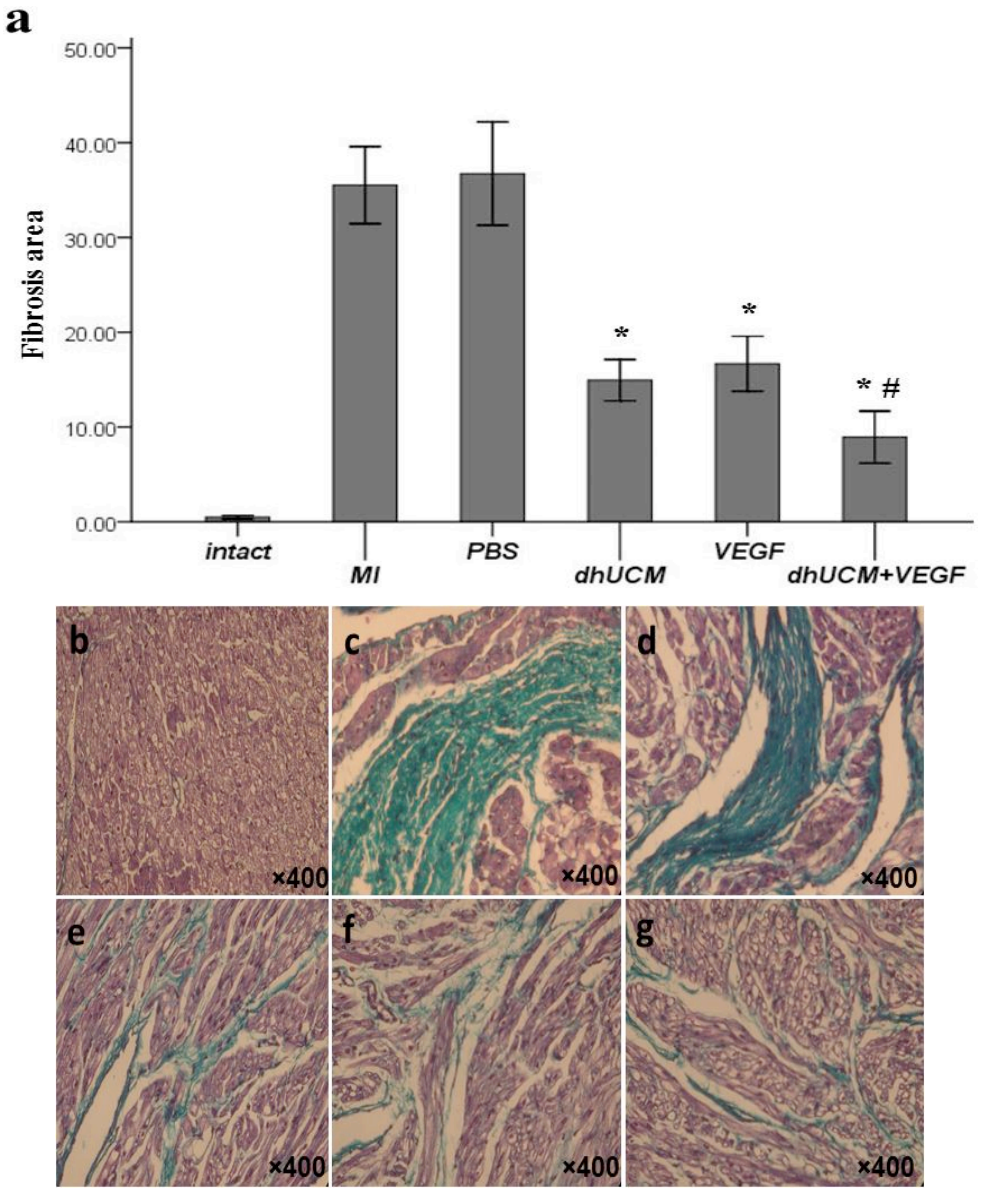

Fig. (8). Fibrosis tissue formation post MI. bar graphs showing the quantification of fibrosis tissue formation in myocardium (a). Representative micrographs have demonstrated the Masson's Trichrome stained sections taken from experimental animal's hearts 8 weeks post MI in intact (b), MI (c), PBS (d), dhUCM (e), VEGF (f) and dhUCM+VEGF (g) groups, respectively. Scale bar: $100 \mu$.

$* \mathrm{p}<0.05$ vs. MI and PBS.\# $\mathrm{p}<0.05$ vs. dhUCM and VEGF.

\section{Cardiac Differentiation of hUCMCells}

Three weeks after treating hUCM cells with Oxytocin, as given in material and methods, the fibroblast-like shape hUCM cells were turned into flat shape cells with short cytoplasmic extensions as cardiomyocytes. DhUCM cells appeared in striped cytoplasm. The indications of contractile filaments and spontaneous beating of these cells have been observed under microscope (Fig. 4a-c). DhUCM cells were stained positively with some cardiac specific markers including cTnT, sA, cA, which indicated fibrillar, contractile structure of dhUCM cells (Fig. 5), as well as with $\mathrm{Cx} 43$, which is a gap junction protein that is required for cell-tocell interaction (Fig. 5), in green fluorescence. HUCM cells, as a control group, didn't show any cardiac specific proteins (Fig. 5). About $73 \%$ of hUCM cells have been differentiated into cardiomyocytes.

\section{Echocardiographic Measurements}

Echocardiographic assessment of heart function was done at different time points. Five days after the induction of MI (acute phase), echocardiographic measurements have shown that both of the LVEF and LVFS significantly decreased $(p<0.05)$ in all MI groups $(\mathrm{MI}, \mathrm{PBS}$, dhUCM, VEGF, dhUCM + VEGF) compared with the intact group, which indicated that cardiac function was damaged (Fig. 6a,b). There wasn't any significant difference between MI groups at this time point. Four weeks post MI (midterm), LVEF and LVFS increased in dhUCM, VEGF, dhUCM + VEGF groups which indicated that the cardiac function had improved (Fig. 6a,b). The animals in dhUCM + VEGF group have shown the highest rise in LVEF and LVFS in comparison to the other groups. Moreover, dhUCM and VEGF groups have suggested that cardiac function improved, which is a significant difference $(p<0.05)$ when we compare them with non-treatment groups. Eight weeks post MI (long term), echocardiograms suggested that LVEF and LVFS had continued rising in dhUCM, VEGF and dhUCM + VEGF groups but in comparison with the obtained results from the same groups four weeks post MI, no significant difference $(\mathrm{p}>0.05)$ was observed (Fig. 6a,b). A significant difference $(\mathrm{p}<0.05)$ between treated animal groups (dhUCM, VEGF, dhUCM + VEGF) and non-treated animal groups (MI, PBS) was continued.

\section{Morphometric and Histological Analysis}

Endothelial cells were stained positively with CD31 (Fig. 7). This assessment has shown that vascular density decreases after MI, a significant difference $(\mathrm{p}<0.05)$ between the intact group $(112.6 \pm 3.78)$ and the other ones, but it didn't show any significant difference between MI (54.8 \pm $4.32)$, PBS (57.04 \pm 5.33$)$ and dhUCM (56.16 \pm 4.84$)$ groups 


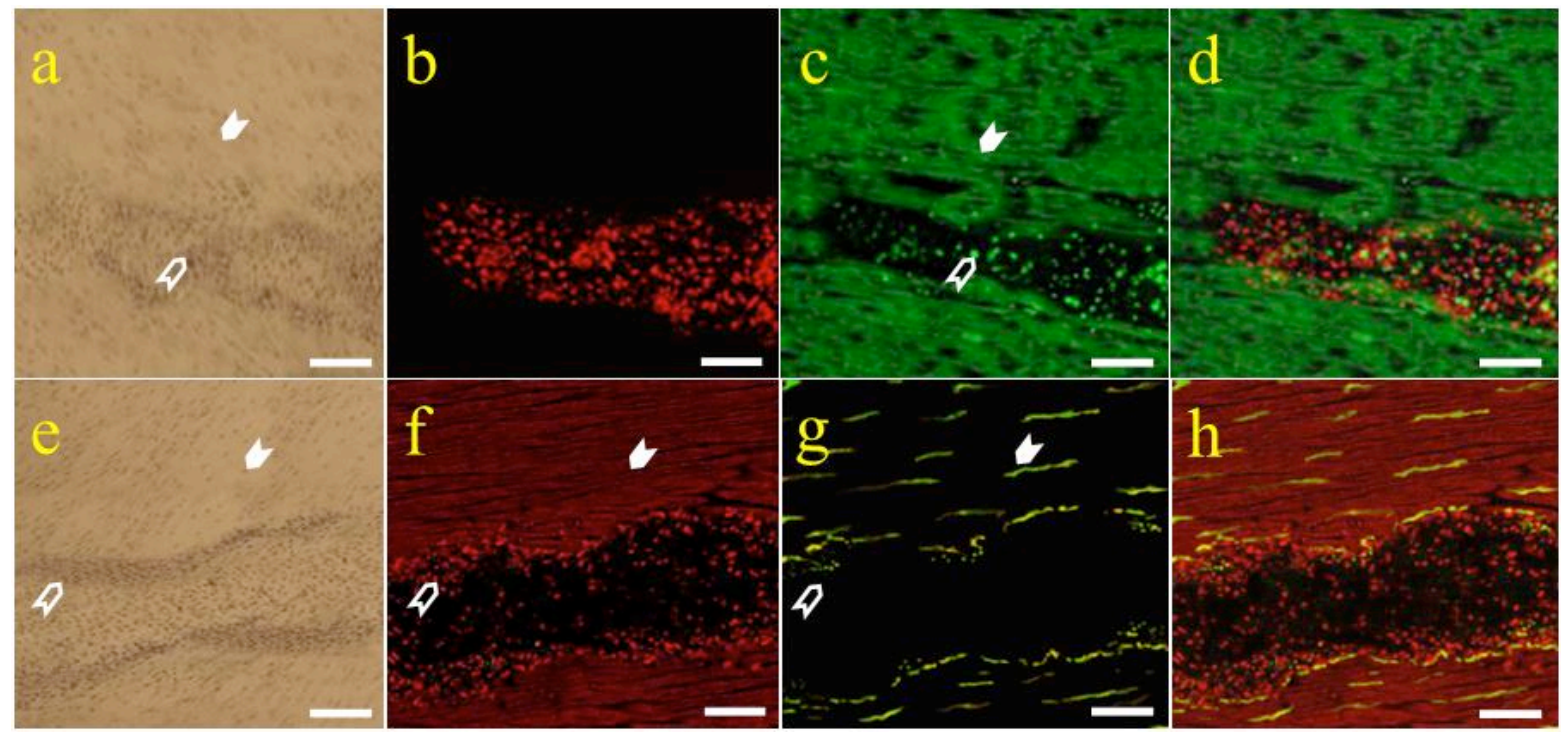

Fig. (9). Transplanted cells (non-filled chevron) and recipient cardiac tissue (filled chevron) after H\&E staining (a \& e). Transplanted DiIlabeled cells appeared in spots within dark zone (b). The $\alpha$ - actinin stained sections that shown integrated area (filled chevron) as a noninfarcted myocardium (c), spots (non-filled chevron) as a dhUCM cells in infarcted area (c) and a merged image of them that indicating survival and migration of transplanted cells in to infarcted myocardium (d). Connexin 43 and cardiac troponin $\mathrm{T}$ positive cells, respectively (f \& g), appeared in both of infarcted area (non-filled chevron) and non-infarcted area (filled chevron), a merged image of them have shown that connexin 43 appeared in border zones between transplanted cells and recipient cardiac tissue (h). Scale bar $=100 \mu \mathrm{m}$.

(Fig. 7a-g). DhUCM + VEGF group has the highest vascular density compared to the other MI groups, which indicates a significant difference $(\mathrm{p}<0.05)$ with MI, PBS and dhUCM groups but not with the VEGF group $(83.54 \pm 1.31)$. Trichromemasson staining was applied to determine the amount of fibrosis tissue formation in myocardium. The fibrosis tissue appeared in green color (Fig. 8). The fields were selected in a similar way like the vascular density evaluation and the obtained images were analysed using MATLAB software. Animals that received dhUCM+VEGF have shown smaller fibrosis $(8.9 \pm 2.21)$ compared to other MI-animal groups, $(\mathrm{p}<0.05)$. Also, animals that received dhUCM cells only $(14.93 \pm 1.75)$ and VEGF only $(16.67 \pm$ 2.33) have represented attenuation of fibrosis tissue formation with a significant difference $(\mathrm{p}<0.05)$ with PBS $(36.73 \pm 4.39)$ and $\mathrm{MI}(35.52 \pm 3.27)$ groups (Fig. 8a-g).

\section{Immunohisto Chemical Analysis}

The survival of dhUCM cells (DiI-labeled cells) is examined by tracking the red cells in cardiac tissue sections under light (Fig. 9a,e) and fluorescence microscope (Fig. 9b). The red spots in the dark zone are determined as transplanted dhUCM cells (Fig. 9b). Having been stained with monocolonal anti- $\alpha$-actin in antibody ( $\alpha$-actinin), the dark zone turns into green. Integrated green areas are noninfarcted areas, and non-integrated areas represent infarcted areas that contain transplanted cells which appeared in the green spots (Fig. 9c). Merged pictures have shown that transplanted cells survive and migrate to the infracted; they alsoshow heart specific marker ( $\alpha$-actinin) (Fig. 9d). The sections were stained with cTnT. The red zones in the infarcted area represent cardiogenic entity of the transplanted cells, and integrated red zones are the recipient cardiac tissue (Fig. 9f). Moreover, sections that underwent staining with $\mathrm{Cx} 43$ and green fluorescence demonstrated $\mathrm{Cx} 43$ in both of the infarcted and non-infarcted areas (Fig. 9g). The pictures have been merged; green spots between cardiac tissue and transplanted cells indicate that transplanted cells integrate with the recipient cardiac tissue and $\mathrm{Cx} 43$, which is a requirement for electrical cell-to-cell coupling that exists between them (Fig. 9h). This integration proves the existence of functional solidarity of dhUCM cells and the recipient cardiac tissue.

\section{DISCUSSION}

In the present study, we have investigated the effects of direct intramyocardial injection of dhUCM cells combined with VEGF on cardiac repair. The achieved data indicates that intramyocardial injection of dhUCM cells combined with VEGF improves left ventricular function, enhances angiogenesis and attenuates fibrosis tissue in infarcted myocardium eight weeks after MI. Recent studies in the field ofcell therapy have shown new therapeutic potentials in the treatment of cardiac disease [27]. Previous studies had shown that various stem cell resources such as; bone marrow (BM-MSCs) [28], Embryonic (ESCs) [29], adipose tissue (ADCs) [12, 30], cardiac (CSCs) [31] and umbilical cord blood stem cells (UCBSCs) [32] have beneficial effects on the restoration of cardiac function after MI, but practical application of these sources is limited. Low cell yields, invasive collection procedure, long culture periods, ethical issues and the risk of recipient immune reaction are but a few of the associated problems that prove to be serious and troublesome barriers in choosing a sufficient stem cell source. Trapped MSCs in hUCM (Wharton's jelly) provide sufficient source of stem cells as a hUCM-MSCs. They are obtained from the umbilical cord that routinely discards them at parturition, thus eliminating the concerns related to other stem cell resources [16-20]. The hUCM cells don't face some of the problems associated with other stem cell resources, therefore, we tried to partake of them in this study. The hUCM cells were differentiated into adipogenic, 
osteogenic and chondrogenic linages so as to prove their multi-linage differentiation potential (Fig. 3a-c). Many scientists have administered various stem cells directly to infarcted heart before a differentiation of those cells into cardiogenic in vitro $[11,28,31]$. Latipour et al. have demonstrated that hUCM and dhUCMtransplantation in to infarcted myocardium improved cardiac function thirty days after MI [25]. Although cardiac microenvironment potentially introduced stem cells to cardiomyocyte differentiation, some surveys have revealed that less than $5 \%$ of cardiomyocytes are derived from stem cells in the recipient heart tissue [33-35]. In this regard, approximately one billion cardiomyocytes are lost in post MI, therefore, the number of cardiomyocytes, derived from stem cells in vivo, seems not to be enough to influence the contractility of the injured myocardium [36]. With this in mind, and to prevent maldifferentiation of hUCM cells in cardiac tissue, we induced them to cardiomyocyte differentiation by oxytocin. Although5-azacytidine is known as a routine agent for the induction of cardiogenic differentiation, but conflicting data about its efficacy has been reported [37]. On the other hand, oxytocin, which is another agent, has shown greater potential than that of 5-azacytidine,therefore, we selected oxytocin to increaseand improve the qualification of cardiomyocyte differentiation $[26,38,39]$. The dhUCM cells have shown some contractile proteins such as cardiac actin, cardiac troponin $\mathrm{T}$ and sarcomeric actin as well as connex in 43, which indicates the electrical coupling of them together remarkably (Fig. 5). In this study, EF and FS, in MI groups decreased significantly compared to the intact group, five days post MI, which suggests that the treatment of the injured heart's function (dhUCM, VEGF and dhUCM+VEGF) didn't have any advantage at this point. Four weeks post MI, EF significantly increased in three treated animal groups, compared with the non-treated animal groups, in accordance with Latifpour's results [25]. Although increased EF was significantly higher in dhUCM+VEGF group compared with dhUCM only and VEGF only groups, the difference between the last two groups was trivial and negligible. Eight weeks post MI, EF enhanced in treated animal groups compared with the same measurements from the same groups four weeks after MI, but this difference was not significant. In addition, animals treated by dhUCM cells combined with VEGF have shown the highest rise in $E F$, with significant difference $(p<0.05)$, compared with other MI groups eight weeks post MI. Surveys that investigated synergic effects of stem cell therapy and angiogenesis therapy are rare. Yang et al. have suggested that BM-MSCs combined with HGF (proangiogenic factor) improve cardiac function and angiogenesis, but no significant difference was observed between BM-MCs combined with HGF and non-combined with HGF groups [40]. Also, they couldn't seethe gap junctions between engrafted stem cells and cardiac tissue. Our study indicates that the combination of dhUCM cells and VEGF have more positive effects thanthe sole application of cell therapy or angiogenic therapy in infarcted myocardium. Synergetic effects between dhUCM cells and VEGF may be explained as the following: hUCM cells were differentiated into cardiomyocytes with high quality prior to the vivo administration, therefore delivering the contractile/functional cardiomyocytes to infarcted hearts that prevent the loss and mal-differentiation of hUCM cells in cardiac microenvironment. The dhUCM cells, before and after transplantation, demonstrated $\mathrm{Cx} 43$ expression as a gap junction protein; in addition, $\mathrm{Cx} 43$ was observed between engrafted cells and host cardiac tissue (Fig. 9g). Optimal delivery route for cell therapy was unclear, but it seems that directintramyocardial injection results in a large numbers of transplanted cells that accumulated in the infarcted border zone, and then migrated to the infarcted area [41]. Also, we delivered a considerable number of cardiomyocytes to infarcted myocardium that fused with the host cardiomyocytes, and integrated functionally with the recipient cardiac tissue. On the other hand, VEGF diminished cardiomyocyte apoptosis, stimulated cell proliferation, andmediated the migration of cardiac stem cells to infarcted myocardium post MI $[30,42,43]$. According to the above statements, we delivered and protected enough cardiomyocytes in ischemic hearts that hypothetically participated in cardiac regeneration, but the exact mechanism of how they function remains unclear yet. Histopathological analysis has revealed that vascular density enhanced significantly in VEGFand dhUCM + VEGF groups compared to the other groups. No significant difference in vascular density was observed between VEGF and dhUCM+VEGF groups. Despite the beneficial effect of dhUCM cells on cardiac function improvement, no angiogenesis was reported. Latifpour et al. have found, by using hematoxylin and eosin staining, there wasn't any significant difference between non-treated animals and treated-animals (with hUCM and dhUCM cells) in number of myocardium's vessels [25]. Lack of the ability to induce angiogenesis is considered as a defect for dhUCM cells, therefore, we eliminated this defect by using VEGF. Many studies have proved that VEGF increases angiogenesis, improves left ventricular function and reduces scar tissue after MI, however, conflicting data about its efficacy was reported that was primarily associated with anexposed dose of it [44-49]. Here we administered 5 $\mu \mathrm{gVEGFin}$ normal saline as a sufficient dose [50]. VEGF injection has shown greater number of vessels in infarcted border zone in VEGF and dhUCM+VEGF groups. VEGF stimulated neovascularization through the induction of growth, proliferation and migration of endothelial cells to infarcted myocardium $[51,52]$ as we observed greater number of CD31 positive vessels in VEGF and dhUCM+VEGF groups (Fig. 7). After MI, injured myocardium and blood vessels were replaced by fibrosis tissue. It has been proved that stem cell engraftment by activating signaling pathways decreases fibrosis tissue [53]. Fibrosis tissue in animalstreated with dhUCM cells was significantly lower than that of MI and PBS groups. We thought that after dhUCM migration and integration with the recipient cardiac tissue, fibroblasts have less chance of finding more space for proliferation and collagen production. VEGF treated animals have shown low fibrosis tissue compared with MI and PBS groups, but no significant difference was observed with the dhUCM group. Previous studies had indicated that VEGF declined scar tissue in infarcted heart $[54,55]$. A possible explanation for the way VEGF decreases fibrosis formation is: VEGF induces the migration of endothelial, CSC and aortic smooth muscle cells to the infarcted area, triggers angiogenesis and facilitates the survival of vessels, promotes the proliferation 
and migration of cardiomyocytes and prevents their deaths by apoptosis. All of the above suggests that the chance of fibroblasts presence inthe infarcted area is limited by the characterized subsequent of VEGF administration. Effects of VEGF only and dhUCM cells only on declining the fibrosis tissue is duplicated in animals treated with both of them together. As a result, the dhUCM+VEGF group has shown the lowest fibrosis tissue formation compared to the other groups (Fig. 8).

In conclusion, we have found that intramyocardial administration of dhUCM cells combined with VEGF can optimize the beneficial effects of dhUCM cells, or the sole administration of VEGF; so simultaneous transplantation of dhUCM cells and VEGF improved cardiac function, enhanced angiogenesis and reduced fibrosis tissue formation after MI, eight weeks post MI.

\section{CONFLICT OF INTEREST}

The authors confirm that this article content has no conflicts of interest.

\section{ACKNOWLEDGEMENTS}

This research has been supported by Tehran University of Medical Sciences \& health services grant No. 17653. We acknowledge Hosein Ahmadi and Saber Ganji for their assistance in surgery and echocardiographic assessments.

\section{REFERENCES}

[1] Gnecchi M, Zhang Z, Ni A, Dzau VJ. Paracrine mechanisms in adult stem cell signaling and therapy. Circ Res 2008;103(11):120419.

[2] Masuda S, Shimizu T, Yamato M, Okano T. Cell sheet engineering for heart tissue repair. Adv Drug Deliv Rev 2008; 60(2): 277-85.

[3] Ahuja P, Sdek P, MacLellan WR. Cardiac myocyte cell cycle control in development, disease, and regeneration. Physiol Rev 2007; 87(2): 521-44.

[4] Pandya NM, Dhalla NS, Santani DD. Angiogenesis-a new target for future therapy. Vasc Pharmacol 2006; 44(5): 265-74.

[5] Ahn A, Frishman WH, Gutwein A, Passeri J, Nelson M. Therapeutic angiogenesis: a new treatment approach for ischemic heart disease-Part II. Cardiology in review. LWW 2008; 16(5): 219-29.

[6] Boodhwani M, Sodha NR, Laham RJ, Sellke FW. The future of therapeutic myocardial angiogenesis. Shock 2006; 26(4): 332-41.

[7] Beohar N, Rapp J, Pandya S, Losordo DW. Rebuilding the Damaged HeartThe Potential of Cytokines and Growth Factors in the Treatment of Ischemic Heart Disease. J Am Coll Cardiol 2010; 56(16): 1287-97.

[8] Barandon L, Couffinhal T, Dufourcq P, et al. Frizzled A, a novel angiogenic factor: promises for cardiac repair. Eur J Cardiothorac Surg 2004; 25(1): 76-83.

[9] Higuchi T, Anton M, Saraste A, et al. Reporter gene PET for monitoring survival of transplanted endothelial progenitor cells in the rat heart after pretreatment with VEGF and atorvastatin. J Nucl Med 2009; 50(11): 1881-6.

[10] Tao Z, Chen B, Tan X, et al. Coexpression of VEGF and angiopoietin-1 promotes angiogenesis and cardiomyocyte proliferation reduces apoptosis in porcine myocardial infarction (MI) heart. Proc Natl Acad Sci USA 2011; 108(5): 2064-9.

[11] Xie X, Cao F, Sheikh AY, et al. Genetic modification of embryonic stem cells with VEGF enhances cell survival and improves cardiac function. Cloning stem cells 2007; 9(4): 549-63.

[12] Bayes-Genis A, Soler-Botija C, Farré J, et al. Human progenitor cells derived from cardiac adipose tissue ameliorate myocardial infarction in rodents. J Mol Cell Cardiol 2010; 49(5): 771-80.

[13] Peng C, Yang K, Xiang P, et al. Effect of transplantation with autologous bone marrow stem cells on acute myocardial infarction. Int J Cardiol 2011; 162(3):158-65
[14] Moretti A, Bellin M, Jung CB, et al. Mouse and human induced pluripotent stem cells as a source for multipotent Isl1+ cardiovascular progenitors. FASEBJ 2010; 24(3): 700-11.

[15] Yang L, Soonpaa MH, Adler ED, et al. Human cardiovascular progenitor cells develop from a KDR+ embryonic-stem-cellderived population. Nature 2008; 453(7194): 524-8.

[16] Wang H, Hung S, Peng S, et al. Mesenchymal stem cells in the Wharton's jelly of the human umbilical cord. Stem cells 2004; 22(7): 1330-7.

[17] Weiss ML, Anderson C, Medicetty S, et al. Immune properties of human umbilical cord Wharton's Jelly-derived cells. Stem cells 2008; 26(11): 2865-74.

[18] Fan C-G, Zhang Q, Zhou J. Therapeutic potentials of mesenchymal stem cells derived from human umbilical cord. Stem cell reviews [Internet]. 2011 Mar [cited 2013 Apr 10];7(1):195-207. Available from: http://www.ncbi.nlm.nih.gov/pubmed/20676943

[19] Taghizadeh RR, Cetrulo KJ, Cetrulo CL. Wharton's jelly stem cells: future clinical applications. Placenta 2011; 32: S311-S315.

[20] Troyer DL, Weiss ML. Concise Review: Wharton's Jelly-Derived cells are a primitive stromal cell population. Stem cells 2008; 26(3): 591-9.

[21] Weiss ML, Medicetty S, Bledsoe AR, et al. Human umbilical cord matrix stem cells: preliminary characterization and effect of transplantation in a rodent model of Parkinson's disease. Stem cells 2006; 24(3): 781-92.

[22] Tsai P, Fu T, Chen YA, et al. The therapeutic potential of human umbilical mesenchymal stem cells from Wharton's jelly in the treatment of rat liver fibrosis. Liver Transplant 2009; 15(5): 48495.

[23] Chao KC, Chao KF, Fu YS, Liu SH. Islet-like clusters derived from mesenchymal stem cells in Wharton's Jelly of the human umbilical cord for transplantation to control type 1 diabetes. PloS one [Internet]. 2008 Jan [cited 2013 Mar 1];3(1):e1451. Available from:

http://www.pubmedcentral.nih.gov/articlerender.fcgi? artid=218019 2\&tool $=$ pmcentrez\&rendertype $=$ abstract

[24] Yang C-C, Shih Y-H, Ko M-H, Hsu S-Y, Cheng H, Fu Y-S. Transplantation of human umbilical mesenchymal stem cells from Wharton's jelly after complete transection of the rat spinal cord. PloS one [Internet]. 2008 Jan [cited 2013 Mar 26]; 3(10):e3336. Available from: http://www.pubmedcentral.nih.gov/articlerender.fcgi? artid $=2566594 \&$ tool $=$ pmcentrez\&rendertype $=$ abstract

[25] Latifpour M, Nematollahi-Mahani SN, Deilamy M, et al. Improvement in cardiac function following transplantation of human umbilical cord matrix-derived mesenchymal cells. Cardiology 2011;120(1): 9-18.

[26] Matsuura K, Nagai T, Nishigaki N, et al. Adult cardiac Sca-1positive cells differentiate into beating cardiomyocytes. J Biol Inorg Chem 2004; 279(12):11384-91.

[27] Li Q, Turdi S, Thomas DP, Zhou T, Ren J. Intra-myocardial delivery of mesenchymal stem cells ameliorates left ventricular and cardiomyocyte contractile dysfunction following myocardial infarction. Toxicol Lett 2010; 195(2-3): 119.

[28] Schenke-Layland K, Strem BM, Jordan MC, et al. Adipose tissuederived cells improve cardiac function following myocardial infarction. J Surg Res 2009; 153(2): 217-23.

[29] Wu KH, Mo XM, Han ZC, Zhou B. Stem cell engraftment and survival in the ischemic heart. Ann Thorac Surg 2011; 92(5): 191725 .

[30] Chen Y, Liu W, Li W, Gao C. Autologous bone marrow mesenchymal cell transplantation improves left ventricular function in a rabbit model of dilated cardiomyopathy. Exp Mol Pathol 2010; 88(2): 311-5.

[31] Van Laake LW, Passier R, Monshouwer-Kloots J, et al. Human embryonic stem cell-derived cardiomyocytes survive and mature in the mouse heart and transiently improve function after myocardial infarction. Stem Cell Res 2007; 1(1): 9-24.

[32] Bollini S, Smart N, Riley PR. Resident cardiac progenitor cells: at the heart of regeneration. J Mol Cell Cardiol 2011; 50(2): 296-303.

[33] Hirata Y, Sata M, Motomura N, et al. Human umbilical cord blood cells improve cardiac function after myocardial infarction. Biochem Biophys Res Commun 2005; 327(2): 609-14.

[34] Jackson KA, Majka SM, Wang H, et al. Regeneration of ischemic cardiac muscle and vascular endothelium by adult stem cells. Journal of Clinical Investigation. Am Soc Clin Investig 2001;107(11): 1395-402. 
[35] Müller-Ehmsen J, Krausgrill B, Burst V, et al. Effective engraftment but poor mid-term persistence of mononuclear and mesenchymal bone marrow cells in acute and chronic rat myocardial infarction. J Mol Cell Cardiol 2006; 41(5): 876-84.

[36] Mangi AA, Noiseux N, Kong D, et al. Mesenchymal stem cells modified with Akt prevent remodeling and restore performance of infarcted hearts. Nat Med 2003; 9(9):1195-201.

[37] Collins SD, Baffour R, Waksman R. Cell therapy in myocardial infarction. Cardiovasc Revasc Med 2007; 8(1):43-51.

[38] Martin-Rendon E, Sweeney D, Lu F, Girdlestone J, Navarrete C, Watt SM. 5-Azacytidine-treated human mesenchymal stem/progenitor cells derived from umbilical cord, cord blood and bone marrow do not generate cardiomyocytes in vitro at high frequencies. Vox sanguinis [Internet]. 2008 Aug [cited 2013 Apr 10]; 95(2):137-48. Available from: http://www.ncbi.nlm.nih.gov/pubmed/18557828

[39] Hollweck T, Hartmann I, Eblenkamp M, et al. Cardiac differentiation of human Wharton's jelly stem cells-experimental comparison of protocols. Open Tissue Eng Regen Med J 2011; 4: 95-102.

[40] Fathi F, Murasawa S, Hasegawa S, Asahara T, Kermani AJ, Mowla SJ. Cardiac differentiation of P19CL6 cells by oxytocin. Int J Cardiol 2009;134(1): 75-81.

[41] Yang ZJ, Ma DC, Wang W, et al. Experimental study of bone marrow-derived mesenchymal stem cells combined with hepatocyte growth factor transplantation via noninfarct-relative artery in acute myocardial infarction. Gene Therp 2006; 13(22): $1564-8$.

[42] Sun Z, Wu J, Fujii H, et al. Human angiogenic cell precursors restore function in the infarcted rat heart: a comparison of cell delivery routes. European journal of heart failure [Internet]. 2008 Jun [cited 2013 Apr 10]; 10(6): 525-33. Available from: http://www.ncbi.nlm.nih.gov/pubmed/18490195

[43] McGinn AN, Nam HY, Ou M, et al. Bioreducible polymertransfected skeletal myoblasts for VEGF delivery to acutely ischemic myocardium. Biomaterials 2011; 32(3): 942-9.

[44] Byrne AM, Bouchier-Hayes DJ, Harmey JH. Angiogenic and cell survival functions of vascular endothelial growth factor (VEGF). J Cell Mol Med 2005; 9(4): 777-94.

[45] Tsoporis JN, Izhar S, Proteau G, Slaughter G, Parker TG. S100BRAGE dependent VEGF secretion by cardiac myocytes induces myofibroblast proliferation. Journal of molecular and cellular cardiology [Internet]. Elsevier Ltd; 2012 Feb [cited 2013 Mar 11];
52(2): 464-73. Available from: http://www.ncbi.nlm.nih.gov/pubmed/21889514

[46] Stewart DJ, Kutryk MJB, Fitchett D, et al. VEGF gene therapy fails to improve perfusion of ischemic myocardium in patients with advanced coronary disease: results of the NORTHERN trial. MolTherp 2009;17(6): 1109-15.

[47] Hariawala MD, Horowitz JR, Esakof D, et al. VEGF improves myocardial blood flow but produces EDRF-mediated hypotension in porcine hearts. J Surg Res 1996; 63(1): 77-82.

[48] Baumgartner I, Rauh G, Pieczek A, et al. Lower-extremity edema associated with gene transfer of naked DNA encoding vascular endothelial growth factor. Ann Intern Med 2000; 132(11): 880-4.

[49] Schwarz ER, Speakman MT, Patterson M, et al. Evaluation of the effects of intramyocardial injection of DNA expressing vascular endothelial growth factor (VEGF) in a myocardial infarction model in the rat-angiogenesis and angioma formation. J Am Coll Cardio $2000 ; 35(5): 1323-30$.

[50] Lee RJ, Springer ML, Blanco-Bose WE, Shaw R, Ursell PC, Blau HM. VEGF gene delivery to myocardium: deleterious effects of unregulated expression. Circulation. Am Heart Assoc 2000; 102(8): 898-901.

[51] Bougioukas I, Didilis V, Ypsilantis $\mathrm{P}$, et al. Intramyocardial injection of low-dose basic fibroblast growth factor or vascular endothelial growth factor induces angiogenesis in the infarcted rabbit myocardium. Cardiovasc Pathol 2007;16(2): 63.

[52] Wang Y, Gabrielsen A, Lawler PR, et al. Myocardial gene expression of angiogenic factors in human chronic ischemic myocardium: influence of acute ischemia/cardioplegia and reperfusion. Microcirculation 2006; 13(3): 187-97.

[53] Vandervelde S, Van Luyn MJA, Rozenbaum MH, Petersen AH, Tio RA, Harmsen MC. Stem cell-related cardiac gene expression early after murine myocardial infarction. Cardiovasc Res 2007; 73(4): 783-93.

[54] Aupperle H, Garbade J, Schubert A, et al. Effects of autologous stem cells on immunohistochemical patterns and gene expression of metalloproteinases and their tissue inhibitors in doxorubicin cardiomyopathy in a rabbit model. Vet Pathol 2007; 44(4): 494503.

[55] Payne TR, Oshima H, Okada M, et al. A relationship between vascular endothelial growth factor, angiogenesis, and cardiac repair after muscle stem cell transplantation into ischemic hearts. J Am Coll Cardiol 2007; 50(17): 1677-84

(C) Kaveh et al.; Licensee Bentham Open.

This is an open access article licensed under the terms of the Creative Commons Attribution Non-Commercial License (http: //creativecommons.org/licenses/by$\mathrm{nc} / 3.0 /)$, which permits unrestricted, non-commercial use, distribution and reproduction in any medium, provided the work is properly cited. 